\title{
Topoedaphic Variability and Patch Burning in Sand Sagebrush Shrubland
}

\author{
Stephen L. Winter, ${ }^{1}$ Samuel D. Fublendorf, ${ }^{2}$ Carla L. Goad, ${ }^{3}$ Craig A. Davis, ${ }^{4}$ and Karen R. Hickman ${ }^{5}$ \\ Authors are ${ }^{1}$ Senior Research Specialist; ${ }^{2}$ Sarkeys Distinguished Professor; ${ }^{3}$ Professor, Department of Statistics, Oklahoma State University, Stillwater, \\ OK 74078, USA; ${ }^{4}$ Associate Professor, and ${ }^{5}$ Professor, Dept of Natural Resource Ecology and Management, Oklahoma State University, Stillwater, OK \\ 74078, USA.
}

\begin{abstract}
Patch burning is the deliberate application of fire to a management unit in a heterogeneous manner, resulting in the heterogeneous distribution of grazing animal impact. The application of patch burning typically has been discussed within a framework of imposing heterogeneity on a homogeneous landscape or management unit, yet most landscapes and management units are actually distinguished by an inherent level of heterogeneity. Within landscapes and management units, differing topography and soils interact to create patterns of contrasting patches, also known as topoedaphic sites. Thus, introduction of a heterogeneous disturbance such as patch burning on a landscape or management unit is more accurately described as the imposition of one layer of heterogeneity onto a pre-existing layer of heterogeneity. We examined effects of patch burning on vegetation structure and animal distribution across contrasting topographical sites in sand sagebrush (Artemisia filifolia Torr.) shrubland of the southern Great Plains in North America. Landscapes at our study site were characterized by an inherent amount of heterogeneity in vegetation structure due to variability in topoedaphic sites, and the patch burning treatment superimposed additional heterogeneity that was constrained by topoedaphic characteristics. Shrub-dominated sites were more dependent on patch burning for heterogeneity of vegetation structure than sites dominated by short grasses. Distribution patterns of cattle (Bos taurus) were not significantly different across treatments, though they followed patterns similar to previous studies. We demonstrated that heterogeneity was dependent on topoedaphic patterns and the application of patch burning management for heterogeneity was dependent on the inherent variability of a landscape.
\end{abstract}

\section{Resumen}

El fuego en parches es una aplicación deliberada de fuego a una unidad de manejo de manera heterogénea que resulta en la distribución heterogénea del pastoreo. La aplicación del fuego en parches se ha discutido normalmente bajo un marco de imponer heterogeneidad en paisajes homogéneos o unidades de manejo, sin embargo la mayoría de los paisajes y unidades de manejo se caracterizan por su inherente nivel de heterogeneidad. Dentro de los paisajes y unidades de manejo las diferencias entre la topografía y el suelo crean patrones de parches contrastantes también conocidos como sitios topoedáficos. Entonces, la introducción de disturbios heterogéneos como el fuego en parches en un paisaje o unidad de manejo es más preciso describirlo como la imposición de una capa de heterogeneidad sobre otra capa existente. Examinamos los efectos del fuego en parches en la estructura vegetal y la distribución de los animales contrastando sitio topográficos en un matorral de Artemisa (Artemisa filifolia Torr.) la parte sur de las Grandes Planicies de los Estados Unidos de América. Los paisajes en nuestra área de estudio se caracterizaron por una cantidad natural de heterogeneidad en la estructura vegetal debido a la variabilidad topoedáfica de los sitios y los tratamientos de fuego en parches sobreimpusieron mas heterogeneidad que estaba limitada por las características topoedáficas. Los sitios dominados por matorrales fueron más dependientes del fuego en parches para la heterogeneidad de la estructura vegetal que los sitios dominados por pastos cortos. La distribución del ganado (Bos taurus) no fue significativamente diferente a lo largo de los tratamientos inclusive estos siguieron patrones similares a estudios anteriores. Demostramos que la heterogeneidad fue dependiente de patrones topoedáficos y la aplicación y manejo del fuego en parches por heterogeneidad fue dependiente de la variabilidad inherente al paisaje.

Key Words: disturbance ecology, fire-grazing interaction, habitat patchiness, heterogeneity, pyric herbivory

\section{INTRODUCTION}

Research was funded from: a State Wildlife Grant under Project T-30-P of the Oklahoma Department of Wildlife Conservation and Oklahoma State University and administered through the Oklahoma Cooperative Fish and Wildlife Research Unit (Oklahoma Department of Wildlife Conservation, Oklahoma State University, United States Geological Survey, United States Fish and Wildife Service and Wildlife Management Institute cooperating); and the National Research Initiative of the USDA Cooperative State Research, Education and Extension Service, grant number 2003-35101-12928.

Correspondence: Stephen L. Winter, Dept of Natural Resource Ecology and Management, Oklahoma State University, Stillwater, OK 74078, USA. Email: stephen.winter@okstate.edu

Manuscript received 15 April 2011; manuscript accepted 28 June 2011.
Fire has a profound influence on large herbivore distribution by concentrating grazing on recently burned areas while areas that have not been recently burned receive light to no grazing impact (Fuhlendorf and Engle 2004; Archibald et al. 2005; Murphy and Bowman 2007; Sensenig et al. 2010). The phenomenon of grazing driven by fire has been termed "pyric-herbivory" and is an expression of the evolutionary interaction of fires, forage quantity and quality, and foraging herbivores (Fuhlendorf et al. 2009). This interaction is described by a model in which both positive and negative 
feedbacks create a shifting mosaic of out-of-phase landscape patches that differ in vegetation structure and composition, amount of herbaceous biomass, and forage quality (Fuhlendorf and Engle 2004; Fuhlendorf et al. 2009). High levels of forage utilization in recently burned patches, and concomitantly low levels of forage utilization in adjacent patches that have not burned recently, result in a landscape mosaic of herbaceous biomass (fuel) that determines the location and behavior of subsequent fires within a landscape (Kerby et al. 2007; Savadogo et al. 2007; Fuhlendorf et al. 2009). Cycles of disturbance and rest driven by this fire-grazing interaction replicate historical dynamics of landscape heterogeneity that are involved in the maintenance of biodiversity in rangeland ecosystems (Fuhlendorf et al. 2009). What has not been determined, however, is how effects of pyric herbivory on landscape heterogeneity may or may not be distinct from other sources of heterogeneity that could be inherent to a landscape in the absence of patch burning. One source of inherent heterogeneity in landscapes is the variation in topographic and edaphic (hereafter topoedaphic) features that can influence vegetation structure and composition (Shumar and Anderson 1986; Parker 1991; Dodd et al. 2002; Davies et al. 2007; Reed et al. 2009). In previous studies of pyric herbivory involving cattle (Bos taurus), the heterogeneity of topoedaphic features across landscapes was inherently minimal or was minimized through study design (Fuhlendorf and Engle 2004; Vermeire et al. 2004; Coppedge et al. 2008).

Patch burning is the deliberate application of fire to a management unit in a manner that is heterogeneous in both space and time (Parr and Andersen 2006). When grazing animals are present within a management unit that has been treated with patch burning, the ensuing distribution of animal impact across the management unit is also heterogeneous (Fuhlendorf and Engle 2004; Vermeire et al. 2004). Thus, restoration of the fire-grazing interaction through patch burning represents the imposition of pyric herbivory upon a landscape or management unit. Patch burning has been proposed as a management strategy that can facilitate a replacement of the prevailing rangeland management paradigm, homogeneous management (Williams 1954; Bailey 2004; Holecheck et al. 2004), with the new paradigm of heterogeneous management (Fuhlendorf and Engle 2001; Fuhlendorf et al. 2009). Application of patch burning in heterogeneous management has potential to contribute to livestock production, invasive species management, and wildlife conservation objectives (Fuhlendorf and Engle 2004; Fuhlendorf et al. 2006; Cummings et al. 2007). Effects of patch burning, and the ability to achieve any management objective through the use of patch burning, likely differ among regions, landscapes, and management units.

Differences among topoedaphic sites within a landscape or management unit may cause differences in the ability of patch burning to impose heterogeneity on a landscape or management unit. Thus, land managers would benefit from increased knowledge of how patch burning effects might vary in space as a result of pre-existing patterns of heterogeneity such as topoedaphic variability. To gain insight into how inherent patterns of landscape heterogeneity might interact with patch burning, we studied a landscape with contrasting topoedaphic features. We quantified the unique effects of patch burning and topoedaphic variability on vegetation structure and cattle distribution in North American sand sagebrush (Artemisia filifolia Torr.) shrubland (nomenclature follows US Department of Agriculture, Natural Resources Conservation Service [USDA-NRCS] 2009b).

\section{METHODS}

\section{Study Location}

The study was conducted at the Hal and Fern Cooper Wildlife Management Area (Cooper WMA) in Woodward County, Oklahoma (long $99^{\circ} 30^{\prime} 05^{\prime \prime} \mathrm{W}$, lat $36^{\circ} 32^{\prime} 10^{\prime \prime} \mathrm{N}$ ). The long-term (1940-2008) average annual precipitation at the study site was $59.9 \mathrm{~cm}$ (www.ncdc.noaa.gov). The annual total precipitation and percent deviation from the long-term average were $72.5 \mathrm{~cm}$ $(121 \%)$ and $40.5 \mathrm{~cm}(68 \%)$ in 2005 and 2006, respectively. Two contrasting topoedaphic sites occurred at Cooper WMA whose soil composition and associated vegetation differed substantially: the Eda-Tivoli soil complex and the Carwile-Eda soil complex. Eda-Tivoli loamy fine sands and fine sands are very deep, rapidly permeable, mixed, thermic Lamellic (Eda part) and Typic (Tivoli part) Ustipsamments that occur as undulating to rolling dunes with slopes of $3-12 \%$ (USDANRCS 2009a). Carwile-Eda loamy and loamy fine sands are very deep, slowly permeable, fine, mixed, superactive, thermic Typic Argiaquolls (Carwile part) that occur between dunes as level to nearly level areas with slopes of $0-5 \%$ (USDA-NRCS 2009a). Clay content and organic matter are lower in Eda and Tivoli soils than in Carwile soils, and potential productivity in years with average precipitation are $2700 \mathrm{~kg} \cdot \mathrm{ha}^{-1}$ for Eda soils, $3400 \mathrm{~kg} \cdot \mathrm{ha}^{-1}$ for Tivoli soils, and $4500 \mathrm{~kg} \cdot \mathrm{ha}^{-1}$ for Carwile soils (USDA-NRCS 2009a). Eda-Tivoli soils were the most prevalent soil-type, representing about $65 \%$ of all soils in the study pastures; Carwile-Eda soils were less common, representing about $9 \%$ of all soils in the study pastures (USDA-NRCS 2009c).

The study region was considered a shrubland with the dominant species being the shrub sand sagebrush (A. filifolia; Collins et al. 1987; Gillen and Sims 2004). At the Cooper WMA study site, plant species associated with Eda-Tivoli soils were sand sagebrush; the perennial tall grasses sand bluestem (Andropogon hallii Hack.) and switchgrass (Panicum virgatum L.); the perennial mid-height grasses little bluestem (Schizachyrium scoparium [Michx.] Nash), sand lovegrass (Eragrostis trichodes [Nutt.] Wood), Texas bluegrass (Poa arachnifera Torr.), and sand dropseed (Sporobolus cryptandrus Torr. Gray); the perennial short grasses thin paspalum (Paspalum setaceum Michx.) and blue grama (Bouteloua gracilis [Willd. ex Kunth] Lag. ex Griffiths); and a variety of perennial and annual forbs including western ragweed (Ambrosia psilostachya DC), annual buckwheat (Eriogonum annuum Nutt.), erect dayflower (Commelina erecta L.), Texas croton (Croton texensis [Klotzsch] Muell.-Arg.), and horse-weed (Conyza canadensis [L.] Cronq.). Sand sagebrush canopy cover on Eda-Tivoli soils can be 20-50\% (Vermeire et al. 2004; Gillen and Sims 2006). Plant species associated with Carwile-Eda soils included the perennial mid-height grasses Texas bluegrass, western wheatgrass (Pascopyrum smithii [Rydb.] A. Löve), and vine-mesquite (Panicum obtusum Kunth); the perennial short 
grasses blue grama and buffalograss (Bouteloua dactyloides [Nutt.] J. T. Columbus); and a variety of forbs including woolly plantain (Plantago patagonica Jacq.), Indian blanket (Gaillardia pulchella Foug.), western ragweed, and Texas croton. Sand sagebrush was sparse to absent in Carwile-Eda soils. All study pastures at Cooper WMA were annually grazed by yearling cattle from 1 April to 15 September. Stocking level in all pastures was approximately 6.85 ha per animal unit ( 1 animal unit $=0.6$ yearling steer). This season of use and stocking level had been the normal practice at these pastures prior to this study and were not changed for the purposes of this study.

\section{Study Design and Sampling}

Four pastures at Cooper WMA were sampled and pasture size was $769-848$ ha (mean $=658$ ha; Fig. 1). In two of the pastures (treatment pastures), one patch representing about one-third of each pasture had been treated with prescribed fire during a previous year (2004 in one treatment pasture and 2005 in the other treatment pasture). The patch that was burned in 2004 was 350 ha and the entire patch (i.e., all 350 ha) was burned. The patch that was burned in 2005 was 204 ha and similarly the entire patch was burned. Both prescribed fires occurred in March of their respective years. The perimeter of each patch that was treated with prescribed fire was delineated with a plowed firebreak and all fires were confined to the area within the firebreaks. Prescribed fires were completed by lighting a backfire on the downwind side of the patch being burned. When a sufficient area had been burned along the downwind side of the patch, flank fires and eventually a head fire were lit to consume all of the fuel within the perimeter of the patch. Cattle had free access to all areas of the treatment pastures during all grazing seasons following prescribed fires. In the remaining two study pastures (control pastures), grazing was the same as previously described, but no large-scale burning had occurred.

We randomly established $12,100-\mathrm{m}$ transects in each of the four pastures and stratified them by topoedaphic site: six transects on Eda-Tivoli topoedaphic sites and six transects on Carwile-Eda topoedaphic sites (Fig. 1). Transects were distributed within pastures so that four transects, stratified by topoedaphic site (two on Eda-Tivoli sites, two on CarwileEda sites), were present in each one-third portion of each pasture. Thus, each control pasture contained 12 transects, stratified by topoedaphic site, and distributed across the pasture. Within the treatment pastures, the unburned area contained eight transects, stratified by topoedaphic site, and each burned patch contained four transects, stratified by topoedaphic site.

During July 2006, percent bare ground, percent cover of litter, percent canopy cover of vegetation structural groups (live and dead vegetation, live and dead grass, live and dead forbs, live and dead shrubs), and the height of the tallest grass, forb, and shrub were quantified within $0.10-\mathrm{m}^{2}$ rectangular $(0.20 \times 0.50 \mathrm{~m})$ plots placed at 2 -m intervals along each transect $(n=50$ plots/transect). Due to a sampling oversight, vegetation height data were not available for four transects in a control pasture and four transects in an unburned patch of a treatment pasture. To assess cattle distribution, frequency of cattle fecal pats and frequency of grass defoliation were

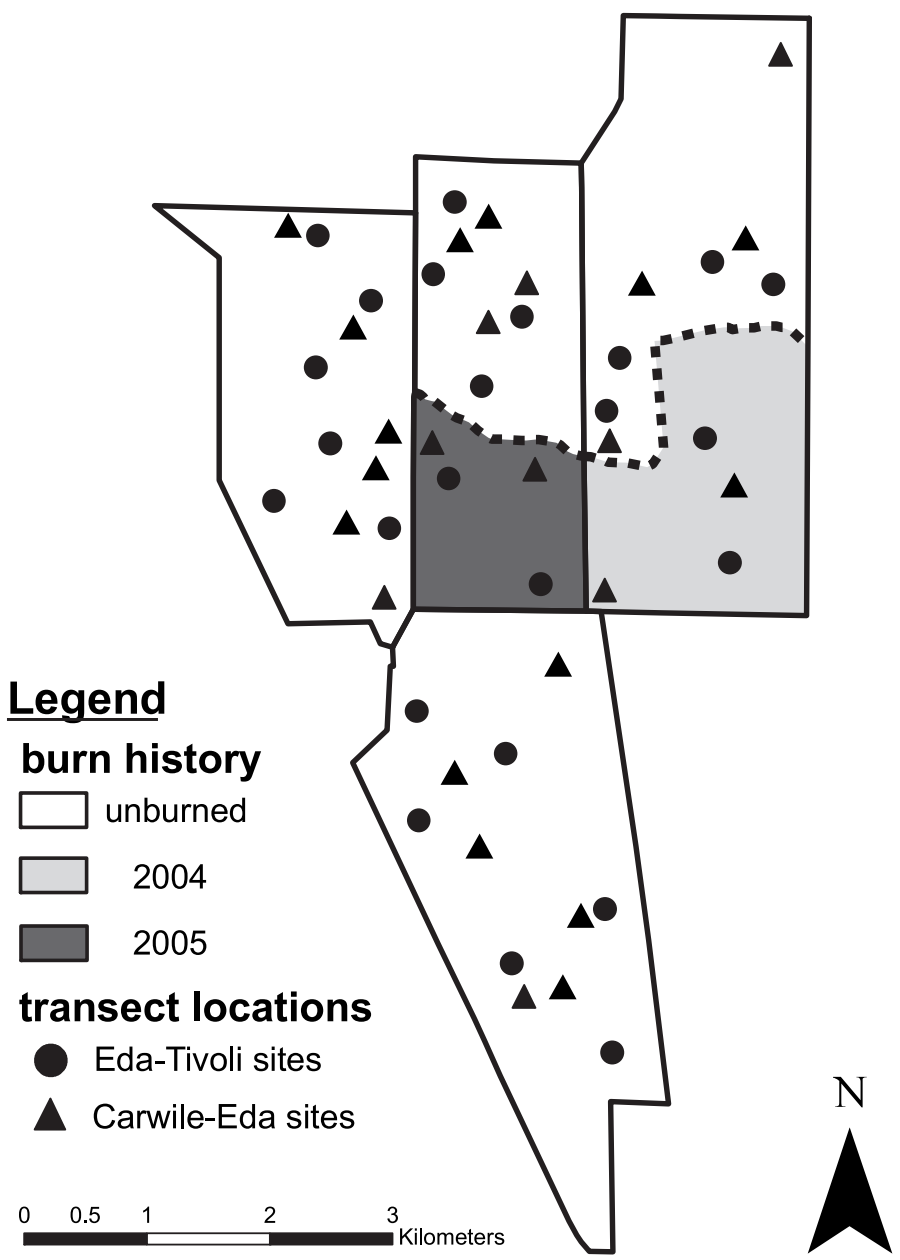

Figure 1. Diagram of study pastures at Cooper Wildlife Management Area in Oklahoma. Two pastures (treatment pastures) were treated with prescribed fire (one pasture in 2004 and the other pasture in 2005) in which approximately one-third of each pasture was burned. The remaining two pastures were not treated with prescribed fire (control pastures). In each pasture, 12 transects were located so that one-third of all the transects were located in approximate one-third portions of each pasture. Within each pasture, the 12 transects were stratified by topoedaphic site; six transects were randomly located on topoedaphic sites characterized by Eda-Tivoli soils (denoted by solid circles) and six transects were randomly located on topoedaphic sites characterized by Carwile-Eda soils (denoted by solid triangles).

quantified within the $0.10-\mathrm{m}^{2}$ plots. Frequency of grass defoliation was determined by presence or absence of at least one blade of grass within a plot that had been clipped at a right angle to the long axis of the blade, following the approach of Dwyer (1961) for determining grazing preferences of cows in tallgrass prairie. Deposition of cattle fecal pats is commonly used to infer cattle distribution (Senft et al. 1983; Bailey and Welling 1999).

\section{Analysis}

We treated all vegetation structural measurements (percent bare ground; percent cover of litter, live and dead vegetation, live and dead grass, live and dead forbs, live and dead shrubs; tallest grass, forb, and shrub) and measurements of cattle distribution (frequency of cattle fecal pats and frequency of 
Table 1. Mean \pm SE vegetation structure and cattle distribution measurements on contrasting topoedaphic sites within treatment categories at Cooper Wildlife Management Area, Oklahoma. Different letters within a row indicate significant differences at the $\alpha=0.05$ level as determined from tests for interactive effects.

\begin{tabular}{|c|c|c|c|c|c|c|}
\hline \multirow[b]{2}{*}{ Response variable } & \multicolumn{2}{|c|}{ Control unburned } & \multicolumn{2}{|c|}{ Treatment burned } & \multicolumn{2}{|c|}{ Treatment unburned } \\
\hline & Carwile-Eda sites & Eda-Tivoli sites & Carwile-Eda sites & Eda-Tivoli sites & Carwile-Eda sites & Eda-Tivoli sites \\
\hline Bare ground & $8.21 \pm 1.42$ & $17.27 \pm 2.08$ & $10.65 \pm 2.81$ & $31.70 \pm 2.81$ & $5.94 \pm 1.46$ & $10.06 \pm 1.93$ \\
\hline Litter & $24.77 \pm 1.80$ & $32.82 \pm 2.05$ & $20.51 \pm 2.82$ & $30.82 \pm 3.45$ & $20.95 \pm 2.02$ & $34.12 \pm 2.54$ \\
\hline Live vegetation & $40.28 \pm 1.93$ & $40.57 \pm 1.93$ & $37.17 \pm 3.27$ & $30.91 \pm 3.07$ & $40.58 \pm 2.36$ & $39.68 \pm 2.35$ \\
\hline Dead vegetation & $53.97 \pm 3.01 \mathrm{ab}$ & $47.27 \pm 3.02 b c$ & $61.40 \pm 5.04 a b$ & $31.47 \pm 4.71 \mathrm{c}$ & $64.12 \pm 3.49 \mathrm{a}$ & $53.76 \pm 3.69 a b$ \\
\hline Live grass & $37.51 \pm 2.11 \mathrm{a}$ & $22.96 \pm 1.77 b$ & $36.67 \pm 3.64 \mathrm{a}$ & $12.47 \pm 2.29 c$ & $37.76 \pm 2.59 \mathrm{a}$ & $24.21 \pm 2.21 b$ \\
\hline Dead grass & $53.10 \pm 3.45$ & $32.64 \pm 3.18$ & $61.08 \pm 5.79$ & $22.39 \pm 4.71$ & $63.57 \pm 4.03$ & $40.34 \pm 4.13$ \\
\hline Live forbs & $6.71 \pm 1.24$ & $7.05 \pm 1.29$ & $3.14 \pm 1.31$ & $6.30 \pm 2.07$ & $7.46 \pm 1.64$ & $6.79 \pm 1.54$ \\
\hline Dead forbs & $5.43 \pm 0.38$ & $5.40 \pm 0.38$ & $5.55 \pm 0.66$ & $6.60 \pm 0.74$ & $5.60 \pm 0.47$ & $5.71 \pm 0.48$ \\
\hline Live shrubs & $0.28 \pm 0.15$ & $19.03 \pm 3.28$ & $0.10 \pm 0.14$ & $18.21 \pm 3.50$ & $0.10 \pm 0.10$ & $18.67 \pm 3.32$ \\
\hline Dead shrubs & $0.16 \pm 0.10$ & $20.19 \pm 1.94$ & $0.15 \pm 0.16$ & $9.74 \pm 1.73$ & $0.19 \pm 0.13$ & $19.94 \pm 2.16$ \\
\hline Fecal pat frequency & $0.16 \pm 0.04$ & $0.01 \pm 0.01$ & $0.21 \pm 0.08$ & $0.04 \pm 0.03$ & $0.11 \pm 0.04$ & $0.00 \pm 0.00$ \\
\hline Grazing frequency & $0.58 \pm 0.08$ & $0.33 \pm 0.07$ & $0.55 \pm 0.13$ & $0.53 \pm 0.13$ & $0.29 \pm 0.08$ & $0.29 \pm 0.08$ \\
\hline Tallest grass & $15.35 \pm 2.04 b$ & $28.40 \pm 1.97 \mathrm{a}$ & $10.15 \pm 2.75 b$ & $13.74 \pm 2.64 b$ & $17.39 \pm 2.44 b$ & $32.77 \pm 2.35 a$ \\
\hline Tallest forb & $8.95 \pm 1.59$ & $18.30 \pm 1.95$ & $6.98 \pm 2.51$ & $15.16 \pm 3.09$ & $9.98 \pm 2.05$ & $17.57 \pm 2.52$ \\
\hline Tallest shrub & $0.65 \pm 0.24$ & $40.67 \pm 2.57$ & $0.29 \pm 0.37$ & $29.02 \pm 4.06$ & $0.29 \pm 0.30$ & $40.82 \pm 3.32$ \\
\hline
\end{tabular}

grazing) as response variables. We treated topoedaphic site (Carwile-Eda and Eda-Tivoli soils) and treatment category (control unburned, treatment burned, treatment unburned) as fixed main effects and conducted significance tests of main effects and the interaction of main effects using the GLIMMIX procedure in SAS (SAS Institute 2007). Random effects included pastures, patches within the pastures, and transects. When necessary, multiple comparisons were conducted using the Tukey-Kramer method (Hsu 1996).

Multivariate analyses were conducted utilizing CANOCO for Windows, version 4.5 (ter Braak and Šmilauer 2002), and percent cover vegetation structure measurements (bare ground, litter, live and dead grass, live and dead forbs, live and dead shrubs) were treated as response variables. We used variance partitioning to determine the amount of variation in the response variables that could be specifically attributed to topoedaphic site or treatment category (Borcard et al. 1992; Volis et al 2011). A redundancy analysis (RDA) was conducted in which the two topoedaphic sites (Carwile-Eda and EdaTivoli soils) and three treatment categories (control unburned, treatment burned, treatment unburned) were treated as distinct environmental variables, generating a sum of all canonical eigenvalues representing the total amount of variation in the data. That was followed by two partial redundancy analyses (pRDAs) in which topoedaphic site and treatment category were alternately treated as an environmental variable and a covariable; the sum of all canonical eigenvalues generated in each pRDA accounted for the amount of variation contributed by an environmental variable when the variation due to the covariable was factored out. Finally, to describe the effect of a topoedaphic site-treatment category interaction on the response variables, an RDA was conducted in which six interaction dummy variables (control unburned on Carwile-Eda soils; control unburned on Eda-Tivoli soils; treatment burned on Carwile-Eda soils; treatment burned on Eda-Tivoli soils; treatment unburned on Carwile-Eda soils; treatment unburned on Eda-Tivoli soils) were created and treated as environmental variables. In all ordination analyses, Monte Carlo tests with 9999 iterations were conducted to assess the significance $(\alpha=0.05)$ of relationships between response variables and canonical axes; other CANOCO settings were maintained at their default settings.

\section{RESULTS}

The interaction of the patch burning treatment and topoedaphic site had a significant effect on percent cover of dead vegetation, live grass, and tallest grass $(P \leq 0.022)$. For percent cover of dead vegetation, there was an effect of topoedaphic site in the burned patches of the treatment pastures where percent cover of dead vegetation was higher $(P \leq 0.001)$ on Carwile-Eda soils than on the Eda-Tivoli soils. An effect of treatment category on percent cover of dead vegetation was found only on the Eda-Tivoli soils where values were lower $(P=0.015)$ in the burned patches of the treatment pastures than in the unburned patches of the treatment pastures (Table 1). There was an effect of topoedaphic site on percent cover of live grass in all treatment categories where values were higher $(P<0.001)$ on Carwile-Eda soils than on Eda-Tivoli soils, and there was an effect of treatment category only on the Eda-Tivoli soils where values were lower $(P=0.024)$ in the burned patches of the treatment pastures than in the unburned patches of the treatment pastures and the control pastures (Table 1). There was an effect of topoedaphic site on the height of the tallest grass within the unburned patches of the treatment pastures and the control pastures where values on the CarwileEda soils were lower $(P \leq 0.001)$ than on the Eda-Tivoli soils, and there was an effect of treatment category only on the EdaTivoli soils where values in the burned patches of the treatment pastures were lower $(P \leq 0.002)$ than in the unburned patches of the treatment pastures and the control pastures (Table 1). 
Table 2. Mean $\pm \mathrm{SE}$ vegetation structure and cattle distribution measurements on contrasting topoedaphic sites at Cooper Wildlife Management Area, Oklahoma. Different letters within a row indicate significant differences at the $\alpha=0.05$ level.

\begin{tabular}{lcr}
\hline Response variable & Carwile-Eda sites & Eda-Tivoli sites \\
\hline Bare ground & $8.06 \pm 1.08 \mathrm{a}$ & $18.12 \pm 1.68 \mathrm{~b}$ \\
Litter & $22.02 \pm 1.33 \mathrm{a}$ & $32.57 \pm 1.60 \mathrm{~b}$ \\
Live vegetation & $39.33 \pm 1.50 \mathrm{a}$ & $36.94 \pm 1.49 \mathrm{a}$ \\
Dead grass & $59.32 \pm 2.65 \mathrm{a}$ & $31.30 \pm 2.52 \mathrm{a}$ \\
Live forbs & $5.42 \pm 0.91 \mathrm{a}$ & $6.71 \pm 0.98 \mathrm{a}$ \\
Dead forbs & $5.53 \pm 0.30 \mathrm{a}$ & $5.88 \pm 0.31 \mathrm{a}$ \\
Live shrubs & $0.14 \pm 0.08 \mathrm{a}$ & $18.63 \pm 1.95 \mathrm{~b}$ \\
Dead shrubs & $0.16 \pm 0.08 \mathrm{a}$ & $15.93 \pm 1.19 \mathrm{~b}$ \\
Tallest forb & $8.64 \pm 1.20 \mathrm{a}$ & $17.01 \pm 1.48 \mathrm{~b}$ \\
Tallest shrub & $0.41 \pm 0.18 \mathrm{a}$ & $36.83 \pm 1.95 \mathrm{~b}$ \\
Fecal pat frequency & $0.16 \pm 0.03 \mathrm{a}$ & $0.01 \pm 0.01 \mathrm{a}$ \\
Grazing frequency & $0.47 \pm 0.06 \mathrm{a}$ & $0.38 \pm 0.06 \mathrm{a}$ \\
\hline
\end{tabular}

Topoedaphic site was significant as a main effect for percent bare ground, percent cover litter, percent cover of live and dead shrubs, tallest forb, and tallest shrub, which were all higher $(P<0.001)$ on Eda-Tivoli soils than on Carwile-Eda soils (Table 2). Treatment was significant as a main effect for percent bare ground, which was higher $(P=0.010)$ in the burned patches of treatment pastures than in the unburned patches of treatment pastures (Table 3).

When topoedaphic site and treatment category were treated as distinct environmental variables in RDA, there was an interaction among treatment and topoedaphic sites such that treatment had a substantial effect within Eda-Tivoli sites but was negligible in Carwile-Eda sites. There was a significant $(P<0.001)$ effect of the environmental variables on the distribution of response variables in ordination space. The sum of all canonical eigenvalues was 0.654 , and eigenvalues for the first, second, third, and fourth axes were 0.604, 0.042, 0.008 , and 0.209 , respectively. When topoedaphic site was treated as a covariable in pRDA, treatment category had a significant effect $(P=0.006)$. The sum of all canonical eigenvalues was 0.068 , and eigenvalues for the first, second, third, and fourth axes were 0.056, 0.012, 0.209, and 0.051, respectively. When treatment category was treated as a covariable, pRDA identified a significant effect of topoedaphic site $(P<0.001)$. The sum of all canonical eigenvalues was 0.585 , and eigenvalues for the first, second, third, and fourth axes were $0.585,0.209,0.051$, and 0.032 , respectively. Variance partitioning showed that topoedaphic site explained $58.5 \%$ of the variation, treatment category explained $6.8 \%$ of the variation in the data, the interaction of treatment category, and topoedaphic site explained $0.1 \%$ of the variation; $34.6 \%$ of the variation in the data was left unexplained.

The RDA using dummy variables representing the interaction of topoedaphic site and treatment category identified the interaction of topoedaphic site and treatment category as a significant $(P<0.001)$ effect on the distribution of response variables in ordination space. The sum of all canonical eigenvalues was 0.691 , and the eigenvalues of the first, second,
Table 3. Mean \pm SE vegetation structure and cattle distribution measurements within treatment categories at Cooper Wildlife Management Area, Oklahoma. Different letters within a row indicate significant differences at the $\alpha=0.05$ level.

\begin{tabular}{lccc}
\hline Response variable & Control unburned & Treatment burned & Treatment unburned \\
\hline Bare ground & $12.03 \pm 1.38 \mathrm{ab}$ & $19.04 \pm 3.17 \mathrm{a}$ & $7.75 \pm 1.29 \mathrm{~b}$ \\
Litter & $28.62 \pm 1.69 \mathrm{a}$ & $25.32 \pm 2.74 \mathrm{a}$ & $27.04 \pm 2.01 \mathrm{a}$ \\
Live vegetation & $40.42 \pm 1.61 \mathrm{a}$ & $33.97 \pm 2.64 \mathrm{a}$ & $40.13 \pm 2.00 \mathrm{a}$ \\
Dead grass & $42.55 \pm 2.83 \mathrm{a}$ & $40.22 \pm 5.01 \mathrm{a}$ & $52.07 \pm 3.54 \mathrm{a}$ \\
Live forbs & $6.88 \pm 1.09 \mathrm{a}$ & $4.46 \pm 1.38 \mathrm{a}$ & $7.12 \pm 1.37 \mathrm{a}$ \\
Dead forbs & $5.41 \pm 0.31 \mathrm{a}$ & $6.05 \pm 0.58 \mathrm{a}$ & $5.66 \pm 0.39 \mathrm{a}$ \\
Live shrubs & $2.51 \pm 0.78 \mathrm{a}$ & $1.44 \pm 1.04 \mathrm{a}$ & $1.49 \pm 0.79 \mathrm{a}$ \\
Dead shrubs & $1.96 \pm 0.63 \mathrm{a}$ & $1.25 \pm 0.70 \mathrm{a}$ & $2.11 \pm 0.76 \mathrm{a}$ \\
Tallest forb & $13.62 \pm 1.26 \mathrm{a}$ & $11.07 \pm 2.00 \mathrm{a}$ & $13.78 \pm 1.63 \mathrm{a}$ \\
Tallest shrub & $20.66 \pm 1.29 \mathrm{a}$ & $14.66 \pm 2.04 \mathrm{a}$ & $20.55 \pm 1.67 \mathrm{a}$ \\
Fecal pat frequency & $0.05 \pm 0.02 \mathrm{a}$ & $0.10 \pm 0.04 \mathrm{a}$ & $0.01 \pm 0.01 \mathrm{a}$ \\
Grazing frequency & $0.46 \pm 0.07 \mathrm{a}$ & $0.54 \pm 0.12 \mathrm{a}$ & $0.29 \pm 0.07 \mathrm{a}$ \\
\hline
\end{tabular}

third, and fourth axes were 0.613, 0.064, 0.010, and 0.003, respectively. An ordination biplot (Fig. 2) of the RDA utilizing the interaction dummy variables identified a gradient associated with topoedaphic site along axis 1 , with percent cover of live and dead grass associated with Carwile-Eda soils and percent bare ground, percent cover litter, and percent cover of live and dead shrubs associated with Eda-Tivoli soils. Axis 2 was characterized by a gradient of differing levels of disturbance created by the fire-grazing interaction on Eda-Tivoli soils: unburned patches of the treatment pastures occupy the lower portions of the gradient, control pastures occupy the middle portions, and burned patches of the treatment pastures occupy the upper portions of the gradient along axis 2. Relative to Eda-Tivoli soils, Carwile-Eda soils were relatively unresponsive to this gradient of disturbance driven by the fire-grazing interaction.

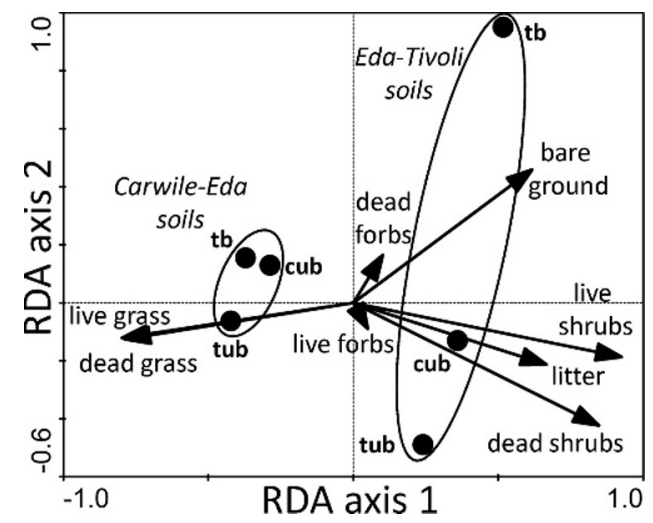

Figure 2. Redundancy analysis (RDA) biplot of vegetation structure measurements using dummy variables accounting for the interaction of topoedaphic site and treatment category, from Cooper Wildlife Management Area, Oklahoma. The topoedaphic sites were characterized by Eda-Tivoli soils or Carwile-Eda soils. Treatment categories were control unburned (cub), treatment burned (tb), and treatment unburned (tub). Interaction dummy variables segregated out along axis 1 by topoedaphic site as indicated by ellipses. Axis 2 reflects a gradient of disturbance intensity. 


\section{DISCUSSION}

Our study differed from previous patch burning research involving cattle (Fuhlendorf and Engle 2004; Vermeire et al. 2004; Fuhlendorf et al. 2006; Coppedge et al. 2008) because it examined the fire-grazing interaction across contrasting topoedaphic sites. While the research of Vermeire et al. (2004) also took place at Cooper WMA, that study controlled for soil heterogeneity by limiting data collection to areas characterized by the Eda and Tivoli soil series. We collected data from topoedaphic sites with contrasting characteristic soil particle sizes, slopes, and vegetation communities with the intent of determining the influence of patch burning on vegetation structure and grazing animal distribution in a complex landscape.

Topoedaphic site had a dominant influence on the vegetation structure of sand sagebrush shrubland at our study site. There was a main effect of topoedaphic site on six variables (bare ground, litter, live shrubs, dead shrubs, tallest forb, and tallest shrub), with those variables consistently higher on the EdaTivoli sites (Table 2). The contrast of vegetation structure between the two topoedaphic sites reflected the contrast in species composition between the sites. Carwile-Eda sites were characterized by sod-forming mid-height and shortgrasses with sand sagebrush being scarce to absent. Eda-Tivoli sites, conversely, were characterized by a diverse mixture of tall and mid-height grasses with the caespitose growth habit being particularly common. Additionally, sand sagebrush was the dominant species on Eda-Tivoli sites. Differences in primary productivity and plant species composition between the two topoedaphic sites at our study site were likely explained by soil-plant water relationships. In arid and semi-arid regions, fine-textured soils are characterized by lower primary productivity because of high evaporative losses from soil surfaces, whereas coarse-textured soils are characterized by higher productivity because percolation of moisture to deeper soil horizons precludes surface evaporation (Noy-Meir 1973).

Plants segregate themselves along gradients of soil texture based on strategies that emphasize either rapid exploitation of surface soil moisture following precipitation events in finetextured soils or utilization of stored soil moisture from deeper horizons in coarse textured soils (Noy-Meir 1973). An example of the effect of soil texture on plant species composition has been described for Sandhills mixed-grass prairie of the northern Great Plains, where differences in water-use efficiencies of various grass species resulted in their segregation along a topoedaphic gradient of coarse sands on a dune slope to finetextured soils of an adjacent lowland (Barnes and Harrison 1982). Similarly, soil-plant water relations have been shown to vary with soil texture and landscape position in North American tallgrass prairie (Knapp et al. 1993) and Great Basin desert (Rosenthal et al. 2005). Differences in soil-plant water relations between the contrasting topoedaphic sites of our study site, resulting in differences in primary productivity and species composition, result in a template of heterogeneity that is inherent to the landscape. This template is present regardless of the imposition of pattern-creating disturbances such as pyricherbivory.

In our study, vegetation structure was altered by the patch burning treatment on Eda-Tivoli sites, with little response on
Carwile-Eda sites (Tables 1 and 2; Fig. 2). Differential effects of disturbance on vegetation communities in different topographical positions have been demonstrated in tallgrass prairie where productivity in lowlands responded positively to fire, whereas productivity in uplands did not (Abrams et al. 1986; Briggs and Knapp 1995). When tallgrass prairie was unburned or burned every $4 \mathrm{yr}$, species composition of uplands was distinct compared with lowlands, but annual burning resulted in the two topographic positions having similar species composition (Gibson and Hulbert 1987). Topography, fire, and grazing can have multiple interactive effects on species composition in tallgrass prairie: effect of grazing on abundance of dominant warm season tall grasses was greater on uplands in annually burned watersheds but greater on lowlands in watersheds burned every $4 \mathrm{yr}$; effect of grazing on species richness was greatest on lowland sites within annually burned watersheds; and grazing had a significant effect on community heterogeneity ( $\%$ dissimilarity in species composition) on uplands and lowlands of annually burned watersheds but only on uplands in watersheds burned every 4 yr (Hartnett et al. 1996).

Topography has a strong influence on cattle distribution with individuals preferring to graze in areas with little slope (Bailey et al. 1996). We, however, did not find a statistically significant effect of topoedaphic site or the patch burning treatment on the measurements of animal distribution we quantified-frequency of cattle fecal pats and frequency of grazed grass plants. However, our data suggested that greater replication of study pastures would result in the detection of a statistically significant effect for one or both of these variables. Mean frequency of cattle fecal pats was $16 \times$ higher on Carwile-Eda soils than on Eda-Tivoli soils (Table 2) and was $10 \times$ higher within burned patches of the treatment pastures than within unburned patches of the same pastures (Table 3). When measurements of animal distribution were broken down by topoedaphic site within treatment categories (Table 1), cattle preferred Carwile-Eda soils over Eda-Tivoli soils in the unburned control pastures, whereas cattle preferred burned patches over unburned patches in the treatment pastures, regardless of topoedaphic site. Patchily distributed fires can have a strong influence on cattle distribution in tallgrass prairie (Fuhlendorf and Engle 2004) and can override the effect of topoedaphic site on distribution of bison (Bison bison L.) in Sandhills mixed-grass prairie (Steuter et al. 1995; Biondini et al. 1999). It is likely that similar results would be detected with cattle in sand sagebrush shrublands with additional research.

Landscape heterogeneity has been deemed important to the persistence of populations and communities of both producers and consumers when total resource or habitat needs can only be met when landscape patches are distinct in space or time (Fryxell et al. 2005; Fuhlendorf et al. 2006; Godfree et al. 2011). The link between species diversity and the heterogeneity of abiotic features, such as topoedaphic site, has been of continuing interest to researchers (Burnett et al. 1998; Nichols et al. 1998; Tews et al. 2004; Lundholm 2009; Parks and Mulligan 2010). Additionally, the role of disturbances in altering ecological patterns of heterogeneity is receiving increased attention (Fraterrigo and Rusak 2008). Our results indicated that landscapes are characterized by an inherent amount of heterogeneity in vegetation structure due to 
variability in topoedaphic features. Furthermore, variance partitioning determined that topoedaphic site explained $58.5 \%$ of the variation in our vegetation structure data. These results suggest the primary determinant of heterogeneity at our study sites was topoedaphic site while the interactive effect of fire and grazing were secondary. However, our results require careful interpretation because we used a balanced sampling design in which equal amounts of data were collected from each topoedaphic site. In actuality, the majority $(65 \%)$ of the landscape at our study site is characterized by Eda-Tivoli soils while Carwile-Eda soils comprise less than $10 \%$ of the landscape. Thus, if we would have allocated data collection within each topoedaphic site in a manner that was proportional to the area represented by each topoedaphic site, it is likely the data would have indicated a more pronounced effect of the patch burning treatment on vegetation structure. Additionally, the effect of pyric-herbivory on primary production has been shown to have cascading effects on higher trophic levels in multiple ecosystems (Fuhlendorf et al. 2006; Yarnell et al. 2007; Coppedge et al. 2008; Engle et al. 2008; Fuhlendorf et al. 2010; Nkwabi et al. 2010), so it follows that patch burning would have substantial ecosystem effects at our study site because the majority of the landscape (i.e., Eda-Tivoli topoedaphic sites) is influenced by this interactive disturbance. Nonetheless, at our study site in sand sagebrush shrubland, an inherent level of heterogeneity in vegetation structure was present as a result of contrasting topoedaphic sites, while the patch burning treatment superimposed an additional layer of heterogeneity that was constrained by topoedaphic characteristics.

\section{MANAGEMENT IMPLICATIONS}

Patch-burning has been demonstrated to be a viable management practice to enhance livestock production (Fuhlendorf and Engle 2004) and management of invasive species (Cummings et al. 2007). The shifting mosaic of habitat patches that result from patch-burning is likely particularly valuable for wildlife conservation objectives and the maintenance of biodiversity (Fuhlendorf et al. 2006; Coppedge et al. 2008; Engle et al. 2008; Fuhlendorf et al. 2009). Land managers are more likely to adopt a novel management strategy, such as patch burning, if they are able to confidently predict the outcomes of their actions within the context of the ecosystems that characterize the areas they manage. Our study demonstrates that landscapes can be characterized by an inherent level of heterogeneity and that the imposition of an additional layer of heterogeneity through patch burning can have differential effects depending on the characteristics of landscape features such as topoedaphic site.

\section{ACKNOWLEDGMENTS}

Assistance with field work was provided by S. Robertson, E. Doxon, J. Bryant, and C. Walden. The USDA Southern Plains Research Range provided housing and logistical support, and E. Wilson and R. Perry of the Oklahoma Department of Wildlife Conservation provided invaluable assistance during the study. D. Shoup provided assistance with statistical analyses and manuscript review for an earlier version of the manuscript. M. Palmer and E. Shahriary provided guidance with ordination analyses. Any use of trade, product, or firm names is for descriptive purposes only and does not imply endorsement by the US Government.

\section{LITERATURE CITED}

Abrams, M. D., A. K. Knapp, and L. C. Hulbert. 1986. A ten-year record of abovebground biomass in a Kansas tallgrass prairie: effects of fire and topographic position. American Journal of Botany 73:1509-1515.

Archibald, S., W. J. Bond, W. D. Stock, and D. H. K. Fairbanks. 2005. Shaping the landscape: fire-grazer interactions in an African savanna. Ecological Applications 15:96-109.

BAILEY, D. W. 2004. Management strategies for optimal grazing distribution and use of arid rangelands. Journal of Animal Science 82:E147-E153.

Balley, D. W., J. E. Gross, E. A. Laca, L. R. Rittenhouse, M. B. Coughenour, D. M. Swift, AND P. L. Sims. 1996. Mechanisms that result in large herbivore grazing distribution patterns. Journal of Range Management 49:386-400.

Bailey, D. W., And G. R. Welling. 1999. Modification of cattle grazing distribution with dehydrated molasses supplement. Journal of Range Management 52:575-582.

Barnes, P. W., and A. T. Harrison. 1982. Species distribution and community organization in a Nebraska Sandhills mixed prairie influenced by plant/soilwater relationships. Oecologia 52:192-201.

Biondini, M. E., A. A. Steuter, And R. G. Hamilton. 1999. Bison use of fire-managed remnant prairies. Journal of Range Management 52:454-461.

Borcard, D., P. Legendre, and P. Drapeau. 1992. Partialling out the spatial component of ecological variation. Ecology 73:1045-1055.

BRIGGS, J. M., AND A. K. Knapp. 1995. Interannual variability in primary production in tallgrass prairie: climate, soil moisture, topographic position, and fire as determinants of aboveground biomass. American Journal of Botany 82:1024-1030.

Burnett, M. R., P. V. August, J. H. Brown, and K. T. Killingbeck. 1998. The influence of geomorphological heterogeneity on biodiversity. I. A patch-scale perspective. Conservation Biology 12:363-370.

Coluins, S. L., J. A. Bradford, and P. L. Sims. 1987. Succession and fluctuation in Artemisia dominated grassland. Vegetatio 73:89-99.

Coppedge, B. R., S. D. Fuhlendorf, W. C. Harrell, and D. M. Engle. 2008. Avian community response to vegetation and structural features in grasslands managed with fire and grazing. Biological Conservation 141:1196-1203.

Cummings, D. C., S. D. Fuhlendorf, and D. M. Engle. 2007. Is altered grazing selectivity of invasive forage species with patch burning more effective than herbicide treatments? Rangeland Ecology \& Management 60:253-260.

Davies, K. W., J. D. Bates, and R. F. Miller. 2007. Environmental and vegetation relationships of the Artemisia tridentata spp. wyomingensis alliance. Journal of Arid Environments 70:478-494.

Dodd, M. B., W. K. Lauenroth, I. C. Burke, and P. L. Chapman. 2002. Associations between vegetation patterns and soil texture in the shortgrass steppe. Plant Ecology 158:127-137.

DwYER, D. D. 1961. Activities and grazing preferences of cows with calves in northern Osage County, Oklahoma. Stillwater, OK, USA: Oklahoma Agricultural Experiment Station. $61 \mathrm{p}$.

Engle, D. M., S. D. Fuhlendorf, A. Roper, and D. M. Leslie, Jr.. 2008. Invertebrate community response to a shifting mosaic of habitat. Rangeland Ecology \& Management 61:55-62.

Fraterrigo, J. M., and J. A. Rusak. 2008. Disturbance-driven changes in the variability of ecological patterns and processes. Ecology Letters 11:756-770.

Fryxell, J. M., J. F. Wilmshurst, A. R. E. SinclaiR, D. T. Haydon, R. D. Holt, and P. A. Aвrams. 2005. Landscape scale, heterogeneity, and the viability of Serengeti grazers. Ecology Letters 8:328-335.

Funlendorf, S. D., AND D. M. Engle. 2001. Restoring heterogeneity on rangelands: Ecosystem management based on evolutionary grazing patterns. BioScience 51:625-632.

Funlendorf, S. D., And D. M. Engle. 2004. Application of the fire-grazing interaction to restore a shifting mosaic on tallgrass prairie. Journal of Applied Ecology 41:604-614. 
Fuhlendorf, S. D., D. M. Engle, J. Kerby, and R. Hamilton. 2009. Pyric herbivory: rewilding landscapes through the recoupling of fire and grazing. Conservation Biology 23:588-598.

Fumlendorf, S. D., W. C. Harrell, D. M. Engle, R. G. Hamilton, C. A. Davis, and D. M. LESLIE, Jr.. 2006. Should heterogeneity be the basis for conservation? Grassland bird response to fire and grazing. Ecological Applications 16:1706-1716.

Funlendorf, S. D., D. E. Townsend, II., R. D. Elmore, and D. M. Engle. 2010. Pyricherbivory to promote rangeland heterogeneity: evidence from small mammal communities. Rangeland Ecology \& Management 63:670-678.

Gibson, D. J., AND L. C. HuLBeRT. 1987. Effects of fire, topography and year-to-year variation on species composition in tallgrass prairie. Vegetatio 72:172-185.

Gillen, R. L., AND P. L. Sims. 2004. Stocking rate, precipitation, and herbage production on sand sagebrush-grassland. Journal of Range Management $57: 148-152$

Gillen, R. L., And P. L. Sims. 2006. Stocking rate and weather impacts on sand sagebrush and grasses: a 20-year record. Rangeland Ecology \& Management $59: 145-152$

Godfree, R., B. Lepschi, A. Reside, T. Bolger, B. Robertson, D. Marshall, and M. Carnegie. 2011. Multiscale topoedaphic heterogeneity increases resilience and resistance of a dominant grassland species to extreme drought and climate change. Global Change Biology 17:943-958.

Hartnett, D. C., K. R. Hickman, and L. E. F. Walter. 1996. Effects of bison grazing, fire, and topography on floristic diversity in tallgrass prairie. Journal of Range Management 49:413-420.

Holecheck, J. L., R. D. Pieper, and C. H. Herbel. 2004. Range management principles and practices. Upper Saddle River, NJ, USA: Pearson-Prentice-Hall. 607 p.

Hsu, J. 1996. Multiple comparisons: theory and methods. London, UK: Chapman and Hall. 296 p.

Kerby, J. D., S. D. Funlendorf, and D. M. Engle. 2007. Landscape heterogeneity and fire behavior: scale-dependent feedback between fire and grazing processes. Landscape Ecology 22:507-516.

Knapp, A. K., J. T. Fahnestock, S. P. Hamburg, L. B. Statland, T. R. Seastedt, and D. S. Schimel. 1993. Landscape patterns in soil-plant water relations and primary production in tallgrass prairie. Ecology 74:549-560.

LundHOLM, J. T. 2009. Plant species diversity and environmental heterogeneity: spatial scale and competing hypotheses. Journal of Vegetation Science 20:377-391.

Murphy, B. P., and D. M. J. S. Bowman. 2007. The interdependence of fire, grass, kangaroos and Australian Aborigines: a case study from central Arnhem Land, northern Australia. Journal of Biogeography 34:237-250.

Nichols, W. F., K. T. Killingbeck, and P. V. August. 1998. The influence of geomorphological heterogeneity on biodiversity. II. A landscape perspective. Conservation Biology 12:371-379.

Nkwabi, A. K., A. R. E. Sinclair, K. L. Metzger, and S. A. R. Mduma. 2010. Disturbance, species loss and compensation: wildfire and grazing effects on the avian community and its food supply in the Serengeti Ecosystem, Tanzania. Austral Ecology 36:403-412.

Noy-MelR, I. 1973. Desert ecosystems: environment and producers. Annual Review of Ecology and Systematics 4:25-51.

PARKER, K. C. 1991. Topography, substrate, and vegetation patterns in the northern Sonoran Desert. Journal of Biogeography 18:151-163.

Parks, K. E., AND M. Mulligan. 2010. On the relationship between a resource-based measure of geodiversity and broad scale biodiversity patterns. Biodiversity and Conservation 19:2751-2766.
Parr, C. L., and A. N. Andersen. 2006. Patch mosaic burning for biodiversity conservation: a critique of the pyrodiversity paradigm. Conservation Biology 20:1610-1619.

Reed, D. N., T. M. Anderson, J. Dempewolf, K. L. Metzger, and S. Serneels. 2009. The spatial distribution of vegetation types in the Serengeti ecosystem: the influence of rainfall and topographic relief on vegetation patch characteristics. Journal of Biogeography 36:770-782.

Rosenthal, D. M., F. LudwiG, and L. A. Donovan. 2005. Plant responses to an edaphic gradient across an active sand dune/desert boundary in the Great Basin Desert. International Journal of Plant Sciences 166:247-255.

SAS InStITUTE. 2007. SAS version 9.2. Cary, NC, USA: SAS Institute.

Savadogo, P., D. Zida, L. Samadogo, D. Tiveau, M. Tigabu, and P. C. Odén. 2007. Fuel and fire characteristics in savanna-woodland of West Africa in relation to grazing and dominant grass type. International Journal of Wildland Fire 16:531-539.

Senft, R. L., L. R. Rittenhouse, and R. G. Woodmansee. 1983. The use of regression models to predict spatial patterns of cattle behavior. Journal of Range Management 36:553-557.

Sensenig, R. L., M. W. Demnent, and E. A. Laca. 2010. Allometric scaling predicts preferences for burned patches in a guild of East African grazers. Ecology 91:2898-2907.

Shumar, M. L., And J. E. Anderson. 1986. Gradient analysis of vegetation dominated by two subspecies of big sagebrush. Journal of Range Management $39: 156-160$

Steuter, A. A., E. M. Steinauer, G. L. Hill, P. A. Bowers, and L. L. Tieszen. 1995. Distribution and diet of bison and pocket gophers in a sandhills prairie. Ecological Applications 5:756-766.

ter Braak, C. J. F., and P. Šmilauer. 2002. CANOCO reference manual and CanoDraw for Windows user's guide: Software for Canonical Community Ordination (version 4.5). Ithaca, NY, USA: Microcomputer Power. 500 p.

Tews, J., U. Brose, V. Grimm, K. Tielbörger, M. C. Wichmann, M. Schwager, and F. Jeltsch. 2004. Animal species diversity driven by habitat heterogeneity/ diversity: the importance of keystone structures. Journal of Biogeography 31:79-92.

[USDA-NRCS] US Department of Agriculture, Natural Resources Conservation Service. 2009a. Official soil series descriptions. Available at: http://soils. usda.gov/technical/classification/osd/index.html2009. Accessed 21 December 2009.

USDA-NRCS. 2009b. The PLANTS database. Available at: http://plants.usda.gov/. Accessed 21 December 2009

USDA-NRCS. 2009c. Web soil survey. Available at: http://websoilsurvey.nrcs. usda.gov. Accessed 21 December 2009.

Vermeire, L. T., R. B. Mitchell, S. D. Fuhlendorf, and R. L. Gillen. 2004. Patch burning effects on grazing distribution. Journal of Range Management $57: 248-252$

Volis, S., M. Dorman, M. Blecher, Y. Sapir, and L. Burdeniy. 2011. Variation partitioning in canonical ordination reveals no effect of soil but an effect of co-occurring species on translocation success in Iris atrofusca. Journal of Applied Ecology 48:265-273.

WiLliams, R. E. 1954. Modern methods of getting uniform use of ranges. Journal of Range Management 7:77-81.

Yarnell, R. W., D. M. Scott, C. T. Chimimba, and D. J. Metcalfe. 2007. Untangling the roles of fire, grazing and rainfall on small mammal communities in grassland ecosystems. Oecologia 154:387-402. 